\title{
Babassu mesocarp bran levels associated with whole or ground corn grains in the finishing of young bulls: carcass and meat characteristics
}

\author{
Aline Evangelista Machado Santana ${ }^{1}$, José Neuman Miranda Neiva ${ }^{1}$, João Restle ${ }^{1}$, Luciano \\ Fernandes Sousa ${ }^{1}$, Fabrícia Rocha Chaves Miotto ${ }^{1}$, Vera Lúcia de Araújo ${ }^{1}$, Wanderson Martins \\ Alencar ${ }^{1}$, Wescley Faccini Augusto ${ }^{1}$
}

\footnotetext{
${ }^{1}$ Universidade Federal do Tocantins, Araguaína, TO, Brasil.
}

\begin{abstract}
The objective of this study was to evaluate the effect of grinding corn and inclusion of babassu mesocarp bran (BMB) in the diet of crossbred dairy young bulls finished in feedlot on their carcass and meat characteristics. Twenty-four young bulls were fed four experimental diets containing two BMB inclusion levels ( 0 and $41.24 \%$ ) and corn in two forms of processing (ground and whole grains) for 98 days, and then slaughtered in a commercial packing plant. Among the quantitative carcass characteristics, there was interaction only in fat trimmings/whole hot carcass weight and cold carcass yield. The whole hot carcass and hot carcass weights showed reduced means with the use of whole corn. The other quantitative variables were not separately affected by BMB inclusion levels or by the form corn was processed. There was interaction between the factors for pistol cut weight, edible portion and weight of the cuts of the pistol cut, in which the use of whole corn and BMB promoted reduction in the mean values. The use of the whole corn grain reduced the participation of flank cut and elevated the participation of the bone fraction in the carcass. Inclusion of $41.24 \%$ of BMB did not change the qualitative meat characteristics, but the use of corn grain resulted in darker meat. The use of whole corn resulted in alteration in the weight of cuts like eye of rump and striploin, which have a high commercial value. There was interaction between factors for the percentages of moisture and minerals of the meat, whereas the crude protein content was affected by the two factors. The use of diets with whole corn or with babassu mesocarp bran may modify the carcass and meat characteristics of finishing crossbred young bulls.
\end{abstract}

Key Words: cold carcass yield, color, hot carcass weight, meat protein

\section{Introduction}

Although feedlot finishing is a technique of easy implantation, its costs are the major obstacle to adopting this procedure. According to Loken et al. (2009), approximately $70 \%$ of the expenses on feedlot production occur with the purchase of feeds, and approximately two-thirds of these expenses are associated with the concentrate feed. Among these feeds traditionally employed in animal production, corn stands out for the large volume utilized, and its use as whole grain has been an alternative for regions of low production of roughages, aiming at lowering the starch fermentation speed, in addition to reducing the costs related to the concentrate feed due to the lower degree of processing of this ingredient.

Because of the large demand for corn in animal production, in addition to other uses such as in human feeding and biofuel production, this feed has shown to be greatly appreciated in the market, causing the profit margin

Received November 24, 2013 and accepted July 2, 2014.

Corresponding author: araguaia2007@gmail.com

http://dx.doi.org/10.1590/S1516-35982014001100007

Copyright $(2014$ Sociedade Brasileira de Zootecnia. This is an Open Access article distributed under the terms of the Creative Commons Attribution Non-Commercial License, which permits unrestricted non-commercial use, distribution, and reproduction in any medium, provided the original work is properly cited. of feedlot to drop (Ferreira et al., 2006). Thus, the adoption of practices that reduce the expenses with feeding are essential so as to reduce the production costs, which would stimulate the use of agro-industrial by-products, especially in regions where the presence of this type of feed is plentiful (Henrique et al., 2006).

Among the by-products, the babassu mesocarp bran (BMB), resulting from the grinding of the mesocarp from the babassu nut, has exhibited good results when utilized in diets for ruminants (Miotto et al., 2012; Silva et al., 2012), and coupled with its attractive commercial value, which can reach a value $65 \%$ lower than corn in certain periods of the year, it is a good option to reduce the feeding costs. The babassu mesocarp bran has been used as a potential source of energy in the feeding of ruminants as a substitute for corn, because it has an average TDN content of $67 \%$; however, its NDF content is close to $45 \%$, which may make it a good option when utilized in diets with a low percentage of roughage for reducing the occurrence of acidosis, since feeds with a high level of fiber do not stimulate production of strong acids like lactate (Klophenstein et al., 2008).

Given the high potential of $\mathrm{BMB}$, the objective was to study its use associated with two forms of including corn grains - whole or ground - in the diet of feedlot young bulls. 


\section{Material and Methods}

The experiment was conducted at municipality of Araguaína, Tocantins, Brazil, located at $07^{\circ} 11^{\prime} 28^{\prime \prime}$ south latitude, $48^{\circ} 12^{\prime} 26^{\prime \prime}$ west longitude and elevation of $227 \mathrm{~m}$. The local climate is tropical humid and the precipitation was $42 \mathrm{~mm}$; maximum and minimum temperatures were 32.77 and $18.7{ }^{\circ} \mathrm{C}$, respectively; average temperature was $25.05^{\circ} \mathrm{C}$; and relative humidity was $76.75 \%$, from April to July 2011.

We utilized a completely randomized design, with treatments distributed in a $2 \times 2$ factorial arrangement (two levels of babassu mesocarp bran and two forms of processing corn), with six replications (animals) per treatment. Twentyfour crossbred young bulls, from crossings between breeds of dairy aptitude, with approximately three years of age and average weight $307.35 \mathrm{~kg}$, were used. The total confinement period was 98 days, 77 of which were used for data collection and 21 days for the animals to acclimate to the experimental diets and facilities. During this period, the animals were treated with endo- and ectoparasites and received vitamins $\mathrm{A}, \mathrm{D}$ and $\mathrm{E}$ via injection. The young bulls were housed in individual, covered, cemented-floor pens provided with individual feeding and drinking troughs for every two animals; each pen had access to a solarium area, where the animals remained for 30 minutes daily, which was the moment when the pens were cleaned.

The ingredients used to formulate the experimental diets were silage, corn, soybean meal and BMB (Table 1). The diets were formulated according to the NRC (2001) so as to contain a similar protein level, aiming at an average daily gain of $1.2 \mathrm{~kg} /$ day (Table 2). The feed was supplied once daily at $14.00 \mathrm{~h}$; the roughage feed utilized was pearl millet silage, which was weighed separately from the concentrate, and both were mixed in the troughs. The amount of feed offered was adjusted daily by collecting and weighing the

Table 1 - Chemical composition of the feeds utilized in the experimental diets

\begin{tabular}{|c|c|c|c|c|}
\hline $\mathrm{g} / \mathrm{kg} \mathrm{DM}$ & $\begin{array}{l}\text { Pearl millet } \\
\text { silage }\end{array}$ & Corn & $\begin{array}{c}\text { Soybean } \\
\text { meal }\end{array}$ & $\begin{array}{c}\text { Babassu } \\
\text { mesocarp bran }\end{array}$ \\
\hline Dry matter ${ }^{1}$ & 180.5 & 854.1 & 864.2 & 884.2 \\
\hline Crude protein & 70.1 & 60.8 & 446.2 & 34.5 \\
\hline Ether extract & 12.7 & 33.9 & 13.3 & 8.1 \\
\hline Neutral detergent fiber & 659.5 & 101.1 & 156.9 & 463.7 \\
\hline Acid detergent fiber & 448.3 & 35.6 & 95.6 & 359.8 \\
\hline Hemicellulose & 211.2 & 65.5 & 61.3 & 103.9 \\
\hline Non-fibrous carbohydrates & 155.4 & 790.8 & 341.6 & 452.1 \\
\hline Total carbohydrates & 814.9 & 891.9 & 498.5 & 915.8 \\
\hline Lignin $^{2}$ & 26.5 & 10.5 & 24.5 & 119.5 \\
\hline Ash & 102.3 & 13.4 & 42.0 & 41.6 \\
\hline
\end{tabular}

${ }^{1} \mathrm{~g} / \mathrm{kg}$ natural matter.

${ }^{2}$ Acid detergent lignin. leftover feed from the previous day, aiming at having $10 \%$ of leftovers from the total supplied.

After the period of 77 days, the animals were slaughtered in a commercial slaughterhouse accredited by the Brazilian Federal Inspection Service (Serviço de Inspeção Federal SIF), located at $12 \mathrm{~km}$ from the site of the experiment. The slaughter weight (SW) was considered that obtained at the weighing performed at the end of the experiment, without previous feed deprivation. After slaughter, the carcasses were washed, sawn in half and weighed; in the cleaning process, the fat trimmings were collected from the half carcasses, so the hot carcass weight (HCW) and the weight of the fat trimmings (FT) were determined.

The whole-carcass weight (WCW) was obtained by summing the hot carcass weight with the respective weights of the fat trimmings. The hot carcass yield and whole hot carcass yield were obtained by using the formulas $\mathrm{HCY}=(\mathrm{HCW} / \mathrm{SW}) \times 100$ and $\mathrm{WHCY}=(\mathrm{WHCW} / \mathrm{SW}) \times 100$, respectively. After the carcasses were cooled in a cold room at $1{ }^{\circ} \mathrm{C}$ for 23 hours, they were weighed again, and so the cold carcass weight $(\mathrm{CCW})$ was determined and then used to determine the cold carcass yield (CCY) and cooling loss $(\mathrm{CL})$, as follows: $\mathrm{CCY}=(\mathrm{CCW} / \mathrm{SW}) \times 100$, and $\mathrm{CL}=$ $[(\mathrm{HCW}-\mathrm{CCW}) / \mathrm{HCW}]^{*} 100$.

Table 2 - Composition of the experimental diets

\begin{tabular}{|c|c|c|c|c|}
\hline \multirow{2}{*}{ Ingredients in $\mathrm{g} / \mathrm{kg} \mathrm{DM}$} & \multicolumn{2}{|c|}{ Ground corn } & \multicolumn{2}{|c|}{ Grain corn } \\
\hline & $0 \mathrm{BMB}$ & 412.4 BMB & $0 \mathrm{BMB}$ & 412.4 BMB \\
\hline & \multicolumn{4}{|c|}{ Proximate composition } \\
\hline Pearl millet silage & 72.0 & 72.0 & 72.0 & 72.0 \\
\hline Ground corn & 818.7 & 360.8 & 0.00 & 0.00 \\
\hline Grain corn & 0.00 & 0.00 & 818.7 & 360.8 \\
\hline Soybean meal & 78.3 & 121.8 & 78.3 & 121.8 \\
\hline Babassu mesocarp bran & 0.00 & 412.4 & 0.00 & 412.4 \\
\hline Mineral $^{1}$ & 18.6 & 20.6 & 18.6 & 20.6 \\
\hline \multirow[t]{2}{*}{ Urea } & 12.4 & 12.4 & 12.4 & 12.4 \\
\hline & \multicolumn{4}{|c|}{ Chemical composition } \\
\hline Dry matter ${ }^{2}$ & 790.2 & 787.4 & 788.4 & 798.1 \\
\hline Crude protein & 112.2 & 112.6 & 117.1 & 114.7 \\
\hline Ether extract & 37.8 & 22.3 & 38.6 & 21.9 \\
\hline Neutral detergent fiber & 170.2 & 285.5 & 168.1 & 282.4 \\
\hline Acid detergent fiber & 79.5 & 215.1 & 78.9 & 219.6 \\
\hline Hemicellulose & 90.7 & 70.4 & 89.2 & 62.8 \\
\hline Non-fibrous carbohydrates & 641.4 & 520.8 & 636.7 & 51.96 \\
\hline Total carbohydrates & 811.6 & 806.3 & 804.8 & 802.0 \\
\hline $\operatorname{Lignin}^{3}$ & 13.6 & 40.4 & 14.0 & 41.2 \\
\hline $\mathrm{NDIN}^{4}$ & 134.4 & 214.9 & 144.7 & 218.7 \\
\hline $\mathrm{ADIN}^{4}$ & 102.4 & 195.8 & 109.8 & 208.0 \\
\hline Ash & 38.4 & 58.8 & 39.5 & 61.4 \\
\hline
\end{tabular}

BMB - babassu mesocarp bran; NDIN - neutral detergent insoluble nitrogen; ADIN acid detergent insoluble nitrogen.

${ }^{1} 188.0 \mathrm{~g} / \mathrm{kg}$ calcium; $74.0 \mathrm{~g} / \mathrm{kg}$ sulfur; $24.0 \mathrm{~g} / \mathrm{kg}$ phosphorus; $30.0 \mathrm{~g} / \mathrm{kg}$ magnesium; $60 \mathrm{~g} / \mathrm{kg}$ sodium; $24 \mathrm{mg} / \mathrm{kg}$ cobalt; $240 \mathrm{mg} / \mathrm{kg}$ fluorine; $720 \mathrm{mg} / \mathrm{kg}$ copper; $40 \mathrm{mg} / \mathrm{kg}$ iodine; $1,500 \mathrm{mg} / \mathrm{kg}$ manganese; $8 \mathrm{mg} / \mathrm{kg}$ selenium; $2,080 \mathrm{mg} / \mathrm{kg}$ zinc; $1,830 \mathrm{mg} / \mathrm{kg}$ monensin sodium.

${ }^{2} \mathrm{~g} / \mathrm{kg}$ natural matter.

${ }^{3}$ Acid detergent lignin.

${ }^{4} \mathrm{~g} / \mathrm{kg}$ of total nitrogen. 
The left half-carcasses were separated into the three primal retail cuts: forequarter (FQ), pistol cut (PC) and flank cut (FC), having their weights measured. The pistol cut was deboned, and the secondary cuts (tail of rump, cap of rump, eye of rump, striploin, tenderloin, cube roll cap, eye of round, silverside, topside, knuckle, shank, thin flank), fat trimmings, bones and meat cuts were weighed. The sum of the secondary cuts of the PC resulted in the weight of the retail cuts (RCW). Summed to the fat trimmings and meat cuts, $\mathrm{RCW}$ was considered the weight of the edible portion of PC (EPPC). On the right half-carcass, conformation and physiological maturity were evaluated, and carcass length (CL), lengths of the leg (LL) and arm (AL), cushion thickness (CT) and arm circumference (AC) were measured (Müller, 1987). The longissimus dorsi muscle was cross-sectioned between the 12th and 13th ribs of the right half-carcass, thereby exposing the muscle surface, where the subcutaneous fat thickness (SFT) was determined. On the same muscle, subjective evaluations of the intramuscular fat (marbling), color and texture of the meat were performed (Müller, 1987). With the aid of tracing paper, the muscle mass was outlined and its area (LDA) was subsequently determined using Image $J^{\circledR}$ software.

The HH section was obtained following the methodology of Hankins and Howe (1946), by separating the longissimus dorsi muscle and freezing it immediately at $-18{ }^{\circ} \mathrm{C}$. The meat chemical composition was analyzed on a sample of the longissimus dorsi. These samples were ground and pre-dried in a forced-circulation oven, and then ground through a $1 \mathrm{~mm}$-screen mill and stored at $-10{ }^{\circ} \mathrm{C}$ for subsequent analyses of moisture, minerals, protein
(Method 920.87; AOAC, 1990) and ether extract, which was determined by washing the samples with petroleum ether at $90{ }^{\circ} \mathrm{C}$.

The data were subjected to homoscedasticity and normality tests; in all quantitative and normal variables, variance analysis and Pearson's correlation were proceeded. The initial weight was utilized as a co-variable, and when not significant, was withdrawn from the model. The mathematical model was represented by:

$$
\gamma \mathrm{ijk}=\mu+\tau \mathrm{i}+\delta \mathrm{j}+\tau \mathrm{i} * \delta \mathrm{j}+\beta \mathrm{k}+a \mathrm{ij}
$$

in which: $\gamma \mathrm{ijk}=$ dependent variable; $\mu=$ overall mean; $\tau \mathrm{i}=$ effect of factor i (inclusion level of babassu mesocarp bran); $\delta \mathrm{j}=$ effect of factor $\mathrm{j}$ (corn processing form); $\left(\tau \mathrm{i}^{*} \delta \mathrm{j}\right)=$ interaction between factor $i$ and factor $j ; \beta k=$ effect of initial weight $\mathrm{k}$; and $a \mathrm{ij}=$ experimental residual error associated with the factorial BMM inclusion level and physical form of corn. The data were subjected to Tukey's test at $5 \%$ significance for comparison between means when the interaction in the studied factors was not significant (above $5 \%$ of significance). For the nonparametric variables, Kruscal Wallis' test was performed, followed by Conover's procedure at 5\% significance for comparison of means, in addition to Spearman's correlation.

\section{Results}

The inclusion level of $\mathrm{BMB}$ and the corn processing form had no interaction $(\mathrm{P}>0.05)$ for the quantitative characteristics (Table 3), except for the fat trimmings/whole hot carcass weight ratio (FTWHCW) and for cold carcass yield (CCY), with reduction when BMB was associated with whole corn grain. However, when BMB was not

Table 3 - Quantitative characteristics of the carcass of crossbred young bulls fed the experimental diets

\begin{tabular}{|c|c|c|c|c|c|c|c|c|}
\hline \multirow{2}{*}{ Variables } & \multicolumn{2}{|c|}{ Ground corn } & \multicolumn{2}{|c|}{ Grain corn } & \multirow{2}{*}{$\mathrm{CV}, \%$} & \multicolumn{3}{|c|}{ P-value } \\
\hline & 0 & 412.4 & 0 & 412.4 & & BMB & GP & $\mathrm{BMB} \times \mathrm{GP}$ \\
\hline $\mathrm{SW}, \mathrm{kg}$ & 447.42 & 423.97 & 419.44 & 418.58 & - & - & - & - \\
\hline TWG, kg & 126.18 & 137.32 & 123.17 & 93.31 & 22.88 & 0.418 & 0.050 & 0.084 \\
\hline WHCW, kg & 229.44 & 236.52 & 221.08 & 218.87 & 4.02 & 0.661 & 0.043 & 0.434 \\
\hline $\mathrm{WHCY}^{1}$ & 51.81 & 56.13 & 54.34 & 50.69 & 11.24 & 0.893 & 0.565 & 0.121 \\
\hline FT, kg & 8.58 & 8.40 & 8.53 & 7.35 & 10.24 & 0.315 & 0.416 & 0.456 \\
\hline FTWHCW $^{2}$ & 3.88 & 3.71 & 3.92 & 3.60 & 24.69 & 0.944 & 0.767 & 0.032 \\
\hline $\mathrm{HCW}, \mathrm{kg}$ & 220.84 & 226.29 & 217.51 & 204.09 & 5.31 & 0.411 & 0.015 & 0.061 \\
\hline $\mathrm{HCY}^{1}$ & 49.88 & 54.14 & 52.28 & 48.94 & 11.32 & 0.856 & 0.573 & 0.129 \\
\hline $\mathrm{CCW}, \mathrm{kg}$ & 208.45 & 221.94 & 210.71 & 203.78 & 4.41 & 0.568 & 0.183 & 0.118 \\
\hline $\mathrm{CCY}^{3}$ & 46.59 & 52.35 & 50.23 & 48.67 & 6.87 & 0.432 & 0.341 & 0.009 \\
\hline $\mathrm{CL}^{4}$ & 4.15 & 2.67 & 2.09 & 3.13 & 63.80 & 0.787 & 0.326 & 0.126 \\
\hline $\mathrm{SFT}, \mathrm{mm}$ & 2.23 & 2.35 & 2.55 & 2.09 & 21.20 & 0.403 & 0.885 & 0.163 \\
\hline $\mathrm{SFT} / 100 \mathrm{~kg}$ & 1.05 & 1.07 & 1.21 & 1.05 & 21.90 & 0.498 & 0.522 & 0.378 \\
\hline
\end{tabular}

BMB - babassu mesocarp bran; GP - grain processing; CV - coefficient of variation.

SW - slaughter weight; TWG - total weight gain; WHCW - whole hot carcass weight; WHCY - whole hot carcass yield; FT - fat trimmings; FTWHCW - fat trimmings/whole hot carcass weight; HCW - hot carcass weight; HCY - hot carcass yield; CCW - cold carcass weight; CCY - cold carcass yield; CL - cooling loss; SFT - subcutaneous fat thickness.

${ }^{1} \mathrm{~kg} / 100 \mathrm{~kg}$ live weight.

${ }^{2} \mathrm{~kg} / 100 \mathrm{~kg}$ whole hot carcass weight.

${ }^{3} \mathrm{~kg} / 100 \mathrm{~kg}$ cold carcass.

${ }^{4} \mathrm{~kg} / 100 \mathrm{~kg}$ hot carcass weight. 


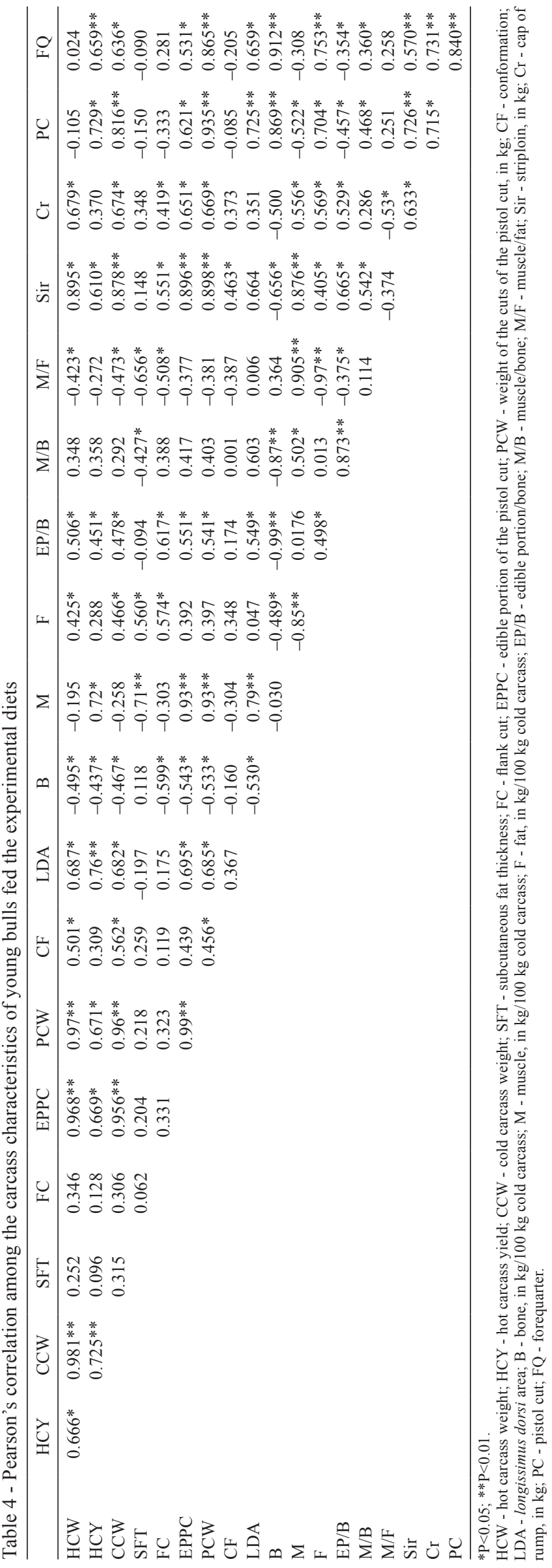

present in the diet, the lowest CCY was observed with the use of ground corn. The animals fed diets with whole corn grains showed lower total weight gain (TWG) in relation to those on the other diets $(\mathrm{P}=0.05)$.

The whole hot carcass weight (WHCW) varied according to the form of processing corn $(\mathrm{P}<0.05)$; it was higher in the animals fed the ground grain. The weight of the fat trimmings in the carcasses in the slaughter line was similar among the treatments, as a result of the similarity of fat cover degrees, confirmed by the similar subcutaneous fat thickness (SFT) of the carcasses. The hot carcass weight $(\mathrm{HCW})$ showed decrease $(\mathrm{P}<0.05)$ in the animals fed diets containing whole corn grains, regardless of the level of inclusion of $\mathrm{BMB}$, with positive correlation between $\mathrm{HCW}$ and TWG $(r=0.666, P=0.0004)$ (Table 4).

The other variables - whole hot carcass yield (WHCY), hot carcass yield (HCY), cold carcass weight (CCW), cooling loss (CL), SFT and SFT/100 kg carcass - did not vary according to the tested factors, averaging $53.24 \mathrm{~kg} / 100 \mathrm{~kg}$, $51.31 \mathrm{~kg} / 100 \mathrm{~kg}, 211.22 \mathrm{~kg}, 3.77 \mathrm{~kg} / 100 \mathrm{~kg}, 2.28 \mathrm{~cm}$ and $1.095 \mathrm{~cm} / 100 \mathrm{~kg}$, respectively. Although no variation was observed in $\mathrm{HCY}$, this variable presented positive correlation with $\mathrm{HCW}, \mathrm{CCW}$, longissimus dorsi area (LDA) and with the muscle content in the carcass $(\mathrm{r}=0.66, \mathrm{P}=0.0004$; $\mathrm{r}=0.981, \mathrm{P}<0.0001 ; \mathrm{r}=0.76, \mathrm{P}<0.0001$ and $\mathrm{r}=0.72$, $\mathrm{P}<0.0001$, respectively), which indicates that animals whose carcasses have greater weight and muscular expression also have better yields.

In the metric measurements made on the carcass, there was significant interaction between the evaluated factors only for leg length ( $L L)(P=0.0041)$, which decreased when the use of whole corn grain was associated with inclusion of $412.4 \mathrm{~g} / \mathrm{kg}$ BMB (Table 5). The other variables presented in Table 5 were not significantly affected by the experimental diets. The score attributed to the carcasses when evaluated regarding conformation and physiological maturity did not show variation either, and both averaged 12.5 , indicating that the animals presented similar muscle development and similar degree of ossification of the cartilages of the spinous processes of the thoracic vertebrae and between the sacral vertebrae. Positive correlation was found between conformation and $\mathrm{HCW}$ and $\mathrm{CCW}(\mathrm{r}=0.501, \mathrm{P}<0.0126$; $\mathrm{r}=0.562, \mathrm{P}<0.0042$, respectively).

Likewise, no significant difference was observed on LDA when expressed as absolute values or relative to $100 \mathrm{~kg}$ of cold carcass, averaging $55.88 \mathrm{~cm}^{2}$ and $26.605 \mathrm{~cm}^{2} / 100 \mathrm{~kg}$ cold carcass. Although no significant correlation with conformation was observed, there was correlation between LDA and CCW ( $r=0.6819$ and $\mathrm{P}=0.0002)$ and muscle content in the carcass $(\mathrm{r}=0.7955$ and $\mathrm{P}<0.0001)$, which 
demonstrates that carcasses with greater LDA are heavier and present more muscularity.

For the variables primal cuts and yield of pistol cut cuts (Table 6), significant interaction of the inclusion level of $\mathrm{BMB}$ and the corn processing form was observed on the absolute weight of $\mathrm{PC}(\mathrm{P}<0.05)$, on the edible portion of the PC (EPPC) and on the retail cuts weight (RCW). The animals which consumed diets with whole corn grains and $\mathrm{BMB}$ exhibited reduction in the absolute weight of the $\mathrm{PC}$ in relation to the other diets, which did not show difference from each other. Mean values for EPPC and $\mathrm{RCW}$, however, were lower when corn was supplied as whole grain, regardless of the BMB inclusion level. Retail cuts weight and EPPC showed negative correlation with the bone content $(\mathrm{r}=-0.5436, \mathrm{P}=0.006 ; \mathrm{r}=-0.5333, \mathrm{P}=0.0073$, respectively) and positive correlation with the muscle content ( $\mathrm{r}=0.9318, \mathrm{P}=0.0001 ; \mathrm{r}=0.9287, \mathrm{P}=0.0001$, respectively). These results indicate that carcasses with a greater portion of muscles and less bone, which corresponded to those of animals that consumed diets with ground or whole corn without BMB, presented greater yield for the cuts of the PC.

Inclusion of $\mathrm{BMB}$ did not affect any of the aforementioned variables; however, the use of whole corn promoted reduction in flank cut (FC), both in absolute and relative values $(\mathrm{P}<0.05)$, and just as $\mathrm{PC}$ and forequarter (FQ) in kilograms, this variable was positively correlated with the fat content in the carcass $(\mathrm{r}=0.574, \mathrm{P}=0.0034$; $\mathrm{r}=0.7036, \mathrm{P}=0.0001 ; \mathrm{r}=0.7531, \mathrm{P}<0.0001$, respectively). The variables bones of $\mathrm{PC}$, in kilograms and in $\mathrm{kg} / 100 \mathrm{~kg}$ of pistol cut, however, did not show variation according to the evaluated diets, averaging $11.14 \mathrm{~kg}$ and $22.55 \mathrm{~kg} / 100 \mathrm{~kg}$ pistol cut, respectively.

Significant interaction was found between the BMB inclusion level and the form of processing of corn on the percentages of muscle and fat and on the muscle/fat ratio $(\mathrm{P}<0.05)$, which showed the same trend observed for the muscle content, in which the use of whole corn in the diet without $\mathrm{BMB}$ and ground corn with $\mathrm{BMB}$ resulted in reduction in the mean values of both variables (Table 7).

However, when the fat content was evaluated, there was interaction between factors with association of whole corn and $\mathrm{BMB}$, which resulted in decrease in the means. The bone content was affected by the form of processing of corn $(\mathrm{P}<0.05)$, having a superior average in the diets with whole corn $(16.13 \mathrm{~kg} / 100 \mathrm{~kg})$ when compared with ground corn $(14.11 \mathrm{~kg} / 100 \mathrm{~kg})$, regardless of the level of

Table 5 - Morphometric measurements of the carcass of young bulls fed the experimental diets

\begin{tabular}{|c|c|c|c|c|c|c|c|c|}
\hline \multirow{2}{*}{ Variables } & \multicolumn{2}{|c|}{ Ground corn } & \multicolumn{2}{|c|}{ Grain corn } & \multirow{2}{*}{$\mathrm{CV}, \%$} & \multicolumn{3}{|c|}{ P-value } \\
\hline & 0 & 412.4 & 0 & 412.4 & & $\mathrm{BMB}$ & GP & $\mathrm{BMB} \times \mathrm{GP}$ \\
\hline Carcass length & 133.33 & 131.35 & 133.33 & 130.16 & 3.23 & 0.159 & 0.741 & 0.737 \\
\hline Arm length & 41.62 & 41.3 & 40.48 & 40.93 & 4.31 & 0.934 & 0.742 & 0.405 \\
\hline Arm circumference & 34.71 & 35.01 & 35.29 & 34.99 & 3.84 & 0.996 & 0.615 & 0.595 \\
\hline Cushion thickness & 24.16 & 25.24 & 23.20 & 24.04 & 5.90 & 0.123 & 0.080 & 0.857 \\
\hline Leg length & 74.13 & 75.7 & 75.10 & 72.32 & 2.42 & 0.549 & 0.242 & 0.041 \\
\hline Conformation & 13.16 & 11.75 & 13.00 & 12.08 & 10.55 & 0.699 & 0.978 & 0.934 \\
\hline Physiological maturity & 12.50 & 10.5 & 12.50 & 14.50 & 4.36 & 1.000 & 0.452 & 0.452 \\
\hline $\mathrm{LDA}, \mathrm{cm}^{2}$ & 56.66 & 57.9 & 55.98 & 52.96 & 8.52 & 0.651 & 0.169 & 0.289 \\
\hline $\mathrm{LDA} / 100 \mathrm{~kg}$ & 26.86 & 26.21 & 26.34 & 26.99 & 8.75 & 0.999 & 0.895 & 0.508 \\
\hline
\end{tabular}

BMB - babassu mesocarp bran; GP - grain processing; CV - coefficient of variation.

LDA - longissimus dorsi area, in $\mathrm{cm}^{2}$ and $\mathrm{cm}^{2} / 100 \mathrm{~kg}$ cold carcass.

Table 6 - Primal cuts of the carcass and yield of pistol cut cuts of young bulls fed the experimental diets

\begin{tabular}{|c|c|c|c|c|c|c|c|c|}
\hline \multirow{2}{*}{ Variables } & \multicolumn{2}{|c|}{ Ground corn } & \multicolumn{2}{|c|}{ Grain corn } & \multirow{2}{*}{$\mathrm{CV}, \%$} & \multicolumn{3}{|c|}{ P-value } \\
\hline & 0 & 412.4 & 0 & 412.4 & & BMB & GP & $\mathrm{BMB} \times \mathrm{GP}$ \\
\hline $\mathrm{PC}, \mathrm{kg}$ & 50.51 & 53.67 & 51.71 & 47.99 & 5.93 & 0.825 & 0.089 & 0.012 \\
\hline $\mathrm{PC}^{1}$ & 48.46 & 48.9 & 49.08 & 47.09 & 4.24 & 0.552 & 0.334 & 0.1646 \\
\hline $\mathrm{FQ}, \mathrm{kg}$ & 43.23 & 48.74 & 43.19 & 39.97 & 6.24 & 0.258 & 0.087 & 0.104 \\
\hline $\mathrm{FQ}^{1}$ & 41.92 & 43.81 & 39.70 & 41.04 & 3.73 & 0.493 & 0.845 & 0.081 \\
\hline $\mathrm{FC}, \mathrm{kg}$ & 12.19 & 39.2 & 11.57 & 10.87 & 7.81 & 0.725 & 0.006 & 0.150 \\
\hline $\mathrm{FC}^{1}$ & 11.48 & 12.63 & 10.99 & 10.67 & 5.75 & 0.798 & 0.002 & 0.096 \\
\hline EPPC, kg & 39.74 & 41.48 & 39.30 & 37.09 & 5.54 & 0.797 & 0.015 & 0.043 \\
\hline RCW, kg & 38.53 & 40.05 & 38.24 & 36.03 & 5.69 & 0.707 & 0.027 & 0.050 \\
\hline $\mathrm{BPC}, \mathrm{kg}$ & 10.77 & 10.05 & 12.41 & 10.9 & 8.43 & 0.681 & 0.629 & 0.222 \\
\hline $\mathrm{BPC}^{2}$ & 21.32 & 22.19 & 23.99 & 22.71 & 8.30 & 0.875 & 0.158 & 0.929 \\
\hline
\end{tabular}

BMB - babassu mesocarp bran; GP - grain processing; CV - coefficient of variation.

PC - pistol cut; FQ - forequarter; FC - flank cut; EPPC - edible portion of the pistol cut; RCW - retail cuts weight; BPC - bones of the pistol cut.

${ }^{1} \mathrm{~kg} / 100 \mathrm{~kg}$ carcass.

${ }^{2} \mathrm{~kg} / 100 \mathrm{~kg}$ pistol cut. 
inclusion of BMB. When the ratios between the tissues that compose the carcass were evaluated, the variables muscle/ bone $(\mathrm{M} / \mathrm{B})$ and edible portion/bone (EP/B) showed significantly superior means in the carcasses of animals that consumed diets containing ground corn, indicating greater participation of edible tissue and smaller bone fraction.

The muscle/fat ratio $(\mathrm{M} / \mathrm{F})$ had a positive correlation with the muscle content $(\mathrm{r}=0.905, \mathrm{P}<0.0001)$ and a negative correlation with the fat content $(\mathrm{r}=-0.977, \mathrm{P}<0.0001)$. The same was observed in the evaluation of the muscle/bone and edible portion/bone ratios. Both showed negative correlation with the bone content $(r=-0.874, P<0.0001 ; r=-0.995$, $\mathrm{P}<0.0001$ ); the muscle/bone ratio was positively correlated with the muscle content $(\mathrm{r}=0.502, \mathrm{P}=0.0043)$ and the edible portion/bone ratio presented positive correlation with the fat content $(r=0.498, P=0.00365)$, demonstrating the influence of the muscle and fat contents in the carcass on these variables. The meat color was also affected by the corn processing form: the animals that consumed whole corn grains had a darker meat than those fed diets with ground corn $(\mathrm{P}<0.05)$. The texture and marbling of the meat, however, did not change, averaging 2.96 and 2.87 points, respectively.

Among the variables that express the chemical composition of the meat, there was interaction on the variables moisture and mineral matter (Table 8); the use of both ground corn and $\mathrm{BMB}$ resulted in reduction of the analyzed means. The crude protein content presented variation both according to the form of processing corn $(\mathrm{P}<0.05)$ and to the level of inclusion of $\mathrm{BMB}(\mathrm{P}<0.05)$, in which the animals fed ground corn or diets containing $\mathrm{BMB}$ presented greater protein concentration in the meat than those fed whole corn or diets without BMB. Among these variables, only ether extract of the meat did not change according to the evaluated diets, averaging $16.2 \mathrm{~g} / \mathrm{kg}$

Of the retail cuts of the PC (Table 9), the factors showed significant interaction for the cuts eye of round and silverside expressed as absolute weight, and thin flank expressed as weight relative to $\mathrm{PC}$, with decrease in these means when BMB and whole corn were present. Likewise, there was interaction of the factors for the percentages of topside, whose proportion reduced with the use of ground corn without $\mathrm{BMB}$, and in the proportion of knuckle when ground corn and $\mathrm{BMB}$ were used, compared with the other diets. The cap of rump and striploin cuts, expressed as absolute weight, were influenced by the corn processing form, and these cuts presented reduction in their weight with the use of whole corn grain in the diet. When the secondary cuts were evaluated in relation to the inclusion levels of BMB, only the proportion of cube roll cap showed significant variation, with increase when BMB was used in the diets.

Table 7 - Physical composition and qualitative characteristics of the carcass of young bulls fed the experimental diets

\begin{tabular}{|c|c|c|c|c|c|c|c|c|}
\hline \multirow{2}{*}{ Variables } & \multicolumn{2}{|c|}{ Ground corn } & \multicolumn{2}{|c|}{ Grain corn } & \multirow{2}{*}{$\mathrm{CV}, \%$} & \multicolumn{3}{|c|}{ P-value } \\
\hline & 0 & 412.4 & 0 & 412.4 & & $\mathrm{BMB}$ & GP & $\mathrm{BMB} \times \mathrm{GP}$ \\
\hline Bones $^{1}$ & 14.34 & 13.88 & 16.31 & 15.95 & 5.39 & 0.423 & 0.004 & 0.925 \\
\hline Muscle $^{1}$ & 68.87 & 65.06 & 63.80 & 68.15 & 2.45 & 0.785 & 0.330 & 0.005 \\
\hline $\mathrm{Fat}^{1}$ & 17.73 & 22.25 & 20.07 & 16.16 & 12.15 & 0.829 & 0.202 & 0.021 \\
\hline Edible portion/bone & 6.05 & 6.30 & 5.19 & 5.28 & 6.00 & 0.432 & 0.002 & 0.716 \\
\hline Muscle/bone & 4.81 & 4.69 & 3.94 & 4.27 & 4.56 & 0.381 & 0.0009 & 0.116 \\
\hline Muscle/fat & 3.99 & 2.90 & 3.23 & 4.26 & 14.69 & 0.921 & 0.363 & 0.014 \\
\hline Color & 2.95 & 2.85 & 2.70 & 2.45 & 22.52 & 0.317 & 0.034 & 0.713 \\
\hline Texture & 2.75 & 2.75 & 2.60 & 3.75 & 16.60 & 0.167 & 0.724 & 0.167 \\
\hline Marbling & 2.50 & 3.00 & 3.50 & 2.50 & 55.86 & 0.758 & 0.674 & 0.435 \\
\hline
\end{tabular}

BMB - babassu mesocarp bran; GP - grain processing; CV - coefficient of variation.

${ }^{1} \mathrm{~kg} / 100 \mathrm{~kg}$ cold carcass.

Table 8 - Chemical composition of the meat of young bulls fed the experimental diets

\begin{tabular}{|c|c|c|c|c|c|c|c|c|}
\hline \multirow{2}{*}{ Variables } & \multicolumn{2}{|c|}{ Ground corn } & \multicolumn{2}{|c|}{ Grain corn } & \multirow{2}{*}{$\mathrm{CV}, \%$} & \multicolumn{3}{|c|}{ P-value } \\
\hline & 0 & 412.4 & 0 & 412.4 & & $\mathrm{BMB}$ & GP & $\mathrm{BMB} \times \mathrm{GP}$ \\
\hline Moisture $^{1}$ & 751.8 & 734.1 & 750.1 & 753.0 & 1.46 & $<0.01$ & $<0.01$ & $<0.01$ \\
\hline Crude protein ${ }^{2}$ & 212.6 & 223.7 & 202.0 & 215.1 & 2.32 & $<0.01$ & $<0.01$ & 0.630 \\
\hline Ether extract ${ }^{2}$ & 14.9 & 17.4 & 16.4 & 16.0 & 20.12 & 0.419 & 0.988 & 0.284 \\
\hline Mineral matter ${ }^{2}$ & 42.8 & 39.4 & 41.0 & 42.2 & 1.42 & $<0.01$ & 0.072 & $<0.01$ \\
\hline
\end{tabular}

BMB - babassu mesocarp bran; GP - grain processing; CV - coefficient of variation.

${ }^{1} \mathrm{~g} / \mathrm{kg}$ natural matter.

${ }^{2} \mathrm{~g} / \mathrm{kg}$ dry matter. 
Table 9 - Cuts of the pistol cut and meat cuts and fat from the pistol cut of young bulls fed the experimental diets

\begin{tabular}{|c|c|c|c|c|c|c|c|c|}
\hline \multirow{2}{*}{ Variables } & \multicolumn{2}{|c|}{ Ground corn } & \multicolumn{2}{|c|}{ Grain corn } & \multirow{2}{*}{$\mathrm{CV}, \%$} & \multicolumn{3}{|c|}{ P-value } \\
\hline & 0 & 412.4 & 0 & 412.4 & & $\mathrm{BMB}$ & GP & $\mathrm{BMB} \times \mathrm{GP}$ \\
\hline Tail of rump, kg & 1.06 & 1.16 & 1.08 & 1.06 & 11.78 & 0.488 & 0.447 & 0.307 \\
\hline Tail of rump ${ }^{1}$ & 2.27 & 2.03 & 2.18 & 2.35 & 8.70 & 0.769 & 0.328 & 0.121 \\
\hline Eye of rump, kg & 2.01 & 2.22 & 2.13 & 1.99 & 6.75 & 0.567 & 0.377 & 0.009 \\
\hline Eye of rump ${ }^{1}$ & 4.14 & 3.98 & 4.12 & 4.31 & 5.65 & 0.911 & 0.313 & 0.256 \\
\hline Striploin, kg & 7.13 & 7.33 & 6.56 & 6.24 & 6.83 & 0.762 & 0.0004 & 0.196 \\
\hline Striploin ${ }^{1}$ & 14.55 & 13.46 & 12.34 & 12.94 & 8.09 & 0.708 & 0.064 & 0.243 \\
\hline Topside, kg & 7.91 & 8.08 & 7.82 & 7.38 & 7.52 & 0.562 & 0.105 & 0.192 \\
\hline Topside $^{1}$ & 16.58 & 14.86 & 14.96 & 15.81 & 4.52 & 0.326 & 0.433 & 0.021 \\
\hline Silverside, $\mathrm{kg}$ & 4.23 & 4.37 & 4.36 & 4.00 & 6.75 & 0.360 & 0.319 & 0.042 \\
\hline Silverside $^{1}$ & 8.91 & 8.13 & 8.14 & 8.48 & 6.78 & 0.534 & 0.538 & 0.154 \\
\hline Shank, kg & 3.72 & 3.76 & 3.90 & 3.62 & 7.48 & 0.338 & 0.866 & 0.173 \\
\hline Shank $^{1}$ & 8.01 & 7.07 & 7.22 & 7.74 & 7.33 & 0.541 & 0.874 & 0.068 \\
\hline Cap of rump, $\mathrm{kg}$ & 1.33 & 1.36 & 1.26 & 1.16 & 9.97 & 0.512 & 0.017 & 0.199 \\
\hline Cap of rump ${ }^{1}$ & 2.73 & 2.57 & 2.43 & 2.45 & 14.14 & 0.747 & 0.350 & 0.692 \\
\hline Knuckle, kg & 4.46 & 4.62 & 4.58 & 4.34 & 7.23 & 0.754 & 0.540 & 0.156 \\
\hline Knuckle $^{1}$ & 9.19 & 8.42 & 8.76 & 9.40 & 5.01 & 0.797 & 0.326 & 0.038 \\
\hline Eye of rump, kg & 3.36 & 3.49 & 3.34 & 3.09 & 7.91 & 0.604 & 0.064 & 0.087 \\
\hline Eye of rump ${ }^{1}$ & 6.90 & 6.51 & 6.27 & 6.70 & 7.04 & 0.944 & 0.436 & 0.194 \\
\hline Tenderloin, kg & 1.65 & 1.78 & 1.69 & 1.61 & 8.88 & 0.661 & 0.299 & 0.076 \\
\hline Tenderloin ${ }^{1}$ & 3.42 & 3.26 & 3.32 & 3.34 & 9.08 & 0.709 & 0.961 & 0.662 \\
\hline Cube roll cap, kg & 1.15 & 1.25 & 0.99 & 1.08 & 22.14 & 0.373 & 0.121 & 0.966 \\
\hline Cube roll cap ${ }^{1}$ & 2.16 & 2.43 & 1.59 & 2.47 & 17.37 & 0.034 & 0.264 & 0.220 \\
\hline Thin flank, kg & 0.49 & 0.59 & 0.49 & 0.44 & 19.04 & 0.623 & 0.081 & 0.066 \\
\hline Thin flank $^{1}$ & 0.90 & 1.11 & 1.03 & 0.84 & 12.92 & 0.876 & 0.350 & 0.040 \\
\hline MT, kg & 1.23 & 1.43 & 1.06 & 1.06 & 26.15 & 0.414 & 0.057 & 0.407 \\
\hline $\mathrm{MT}^{1}$ & 2.57 & 3.00 & 2.03 & 2.38 & 34.08 & 0.454 & 0.281 & 0.942 \\
\hline $\mathrm{FT}, \mathrm{kg}$ & 1.72 & 1.64 & 1.75 & 1.80 & 16.77 & 0.889 & 0.447 & 0.578 \\
\hline $\mathrm{FT}^{1}$ & 3.44 & 3.31 & 3.36 & 3.23 & 16.09 & 0.686 & 0.803 & 0.992 \\
\hline
\end{tabular}

BMB - babassu mesocarp bran; GP - grain processing; CV - coefficient of variation.

MT - meat trimmings; FT - fat trimmings.

${ }^{1} \mathrm{~kg} / 100 \mathrm{~kg}$ pistol cut.

\section{Discussion}

The variation observed in the performance of the confined animals resulted in alteration in WHCW and $\mathrm{HCW}$, and among the evaluated diets none provided the minimum carcass weight required by the packing plants of the region, which is $240 \mathrm{~kg}$, due to the low initial weight and the short period in feedlot to which they were subjected, and this was penalized with lower remuneration, which became equivalent to the price paid for cull cows. It should be noted that the hot carcass weight is an important trait for both the farmer, whose price paid is the product of the carcass weight and of the price paid per kilogram, generating higher remuneration per heavier carcasses, and for the meatpacking industry, since heavier carcasses generate the same operational costs as lighter carcasses, but will ensure greater profitability due to the greater yield of primal and secondary cuts and non-carcass components, whose weights are proportional to the slaughter weight. Feeding animals diets that included ground corn provided greater $\mathrm{HCW}$, and consequently higher revenues than those which included the whole corn, as a consequence of the greater intake of total digestible nutrients and higher average daily gain of animals supplemented with ground corn. However, we emphasize that the process of grinding corn generates an additional cost to the diets, which should be considered in the final economic evaluation.

The fact that no difference was found between the weights of the fat trimmings during cleaning in the slaughter line indicates that the use of diets did not promote differences in losses from excess fat. Because the fat trimmings were similar among treatments, WHCW, which is the sum of the weights of the fat trimmings and $\mathrm{HCW}$, followed the same trend as $\mathrm{HCW}$, and so the animals fed whole corn grain also showed reduction in $\mathrm{WHCW}$. Although there was difference in $\mathrm{HCW}$, the weight of the carcasses after cooling did not indicate variation between the means, so the variation in hot carcass weight possibly disappeared due to the losses of fluids from the carcasses during the cooling process due to the low SFT of the carcasses, which offset the weight difference between them, even though no variation was found for CL.

The evaluation of HCY, WHCY and CCY is important for the packing plants, given that carcasses with lower yields generate the same operational cost as heavier carcasses, resulting in lower profit (Costa et al., 2002). 
These variables correspond to $\mathrm{HCW}$, WHCW and $\mathrm{CCW}$, respectively, acting as a fraction of SW, and increase in the maturity of the animal caused by greater participation of the tissues that compose the carcass and lower proportion of the gastrointestinal tract in relation to SW tend to increase these variables. However, the occurrence of contusions due to fights between animals, poorly applied vaccinations and inappropriate transportation, in addition to excess perirenal fat, may cause it to reduce (Owens et al., 1993). Therefore, it is possible that the low fat content in the carcass contributed to reduce the carcass yields (Fernandes et al., 2009), since the carcasses with lower SFT presented lower CCY. Besides, the fact that the animals utilized in this study are from breeds of dairy aptitude contributed to the low yield observed, because such animals have greater participation of non-carcass components (head, paws, hides and viscera), which reduce the carcass weights and change the yield when removed (Berg and Buterfield, 1976).

Regardless of the diets, SFT remained below the minimum $3 \mathrm{~mm}$ required by the packing plants that prize quality. This variable acts as an indicator of the carcass fat cover; an important factor in the commercialization, since some packing plants value carcasses whose SFT is in the range from 3 to $6 \mathrm{~mm}$. According to Costa et al. (2002), SFT lower than $3 \mathrm{~mm}$ may lower the carcass quality, because it causes greater fluid losses during cooling, results in darkening of the external surface of the muscles that line the carcass and reduces the meat tenderness, thereby undermining its commercialization in the retail market. Although there was no variation in SFT and CL, it is possible that the low fat thickness contributed to the loss of fluids during the carcass cooling, given that those with numerically superior SFT showed lower losses, agreeing with the observation of Costa et al. (2002).

It should be noted that fat deposition in the carcass follows a chronological sequence in which subcutaneous fat deposition is late, so older animals will present greater fat content than younger ones (Owens et al., 1993; Schoonmaker et al., 2002; Casey et al., 2003; McPhee et al., 2006); moreover, large-size-breed and uncastrated animals, like those utilized herein, are even later in fat deposition than small-sized animals (Berg and Buterfield, 1976).

Although the carcass conformation showed to be positively correlated with $\mathrm{HCW}$ and $\mathrm{CCW}$, its evaluation did not show alterations according to the treatments, averaging 12.5, which, according to Müller (1987), corresponds to conformation classified as good to very good. This variable may be scored from 1 to 15 ; carcasses with high scores such as those observed in the present study are more appreciated by the market (Pacheco et al., 2005), having higher commercial values than those with lower conformation in some regions (Álvarez et al., 2012), because they indicate greater participation of the edible tissues than bone in the carcasses and muscles with better appearance (Muller, 1987; Álvarez et al., 2012), given that this tissue corresponds to the main component used to compose the price for the commercialization of the carcass by packing plants.

The absence of variation for LDA and LDA/100 confirms the similarity observed in the degree of muscle development of the carcasses measured by subjective evaluation of the conformation, both related to the carcass muscularity. According to the literature, variations in LDA are due to factors such as differences in the breed groups (Ferreira et al., 2006), in the nutritional level of the diets (Igarasi et al., 2008) and in the sexual status (Climaco et al., 2006). Another factor to influence DLA is the slaughter or carcass weight (Costa et al., 2002); however, although there was difference in carcass weight, this difference did not get to the point of affecting LDA, probably due to the lower magnitude of the differences between weights.

Because no significant difference was observed for the percentages or absolute weight of $\mathrm{PC}$ and $\mathrm{FQ}$ according the use of BMB, it is possible to affirm that inclusion of this bran up to the level of $41.24 \%$ in DM can be recommended, since it does not change the proportion of the main primal cuts of the carcass, and this is an important trait, since the cuts of highest commercial value are located in the pistol cut and a reduction in its proportion would result in lower profitability to the meat packing industry. These results are in line with the observations of Cruz (2012), who worked with two inclusion levels of the bran $(0$ and $350 \mathrm{~g} / \mathrm{kg}$ ) and two levels of concentrate in the diet (650 and $710 \mathrm{~g} / \mathrm{kg}$ ) of Nellore young bulls and did not observe alterations in the commercial cuts by inclusion of BMB or the level of concentrate used.

However, the fact that PC in absolute weight and FC as absolute and relative weight changed when the animals were fed whole corn grains indicates occurrence of distinct body development among the animals, and this alteration is possibly linked to deposition of fat, since PC, FQ and FC had positive correlation with the fat content in the carcass. According to Vaz et al. (2002), fat deposition in the carcass contributes to increase in the primal cuts weight, and thus carcasses with a greater fat cover degree present heavier primal cuts, which results in higher participation of the cuts of highest commercial value in the carcass.

In addition to ensuring higher carcass yields, the production of carcasses that present higher amounts of edible portion also ensures greater preference of the packing plants for these when compared with those with 
higher bone tissue fraction, since the carcass portion of highest commercial value is the meat cuts present in the PC (Alleoni, 1995). In this study, the animals that consumed whole corn grains showed greater proportion of bones in the carcass than those in which corn was provided ground, and these carcasses had lower participation of edible tissue and increase in the bone content, thereby reducing the quality of the carcasses. Considering that alteration in the absolute value of one of the tissues that compose the carcass can cause the relative value of the others to change, it is possible that the higher deposition of muscle and/or fat in the animals that consumed ground corn represented an important factor to promote reduction in the relative participation of bone tissue in these animals, which did not occur in the animals fed whole corn, because the lower deposition of these tissues in these animals resulted in greater bone percentage. According to Berg and Buterfield (1976), this is due to the fact that the energy and protein levels of the diets affect the tissue development, and diets with a higher nutritional value (ground corn) provide greater development of the edible tissues in the carcass without major changes in bone development, given that the later shows greater growth speed in the period before that evaluated. This variation in bone percentage resulted in alteration in the $\mathrm{EP} / \mathrm{B}$ and $\mathrm{M} / \mathrm{B}$ ratios, in which animals whose diets contained ground corn showed higher EP/B and $\mathrm{M} / \mathrm{B}$ than those fed whole corn grain.

As for the qualitative traits, Müller (1987) comments that consumers appreciate meats with a lighter color, tending to reject the darker ones because the latter are associated with older animals. In this study, the color was classified in between dark red and slightly dark; this variable is dependent on the total amount of myoglobins present in the meat, which can be influenced by sex, age, rearing system, presence of pathological processes, and feeding (Ordóñez Pereda et al., 2005). It should be noted that the animals utilized in this study were uncastrated, and according to Vaz and Restle (2000), these animals had darker meat (2.85 points) than castrated animals (4.37 points). The meat from the animals that consumed ground corn presented, on average, a less dark meat - 2.9 points, close to 3, which indicates a slightly dark meat in relation to the animals that consumed whole corn grains - 2.6 points, considered between dark and slightly dark. However, the meat color from all treatments was much lower than 4 (red) and 5 points (bright red), so they would probably be rejected by more demanding consumers, who purchase meat with a redder color. Texture, in turn, did not vary, and this is related to the fact that the animals were slaughtered at the same age, since this variable is directly associated with age, sex and breed, in which large-size breeds present a rougher texture than smaller breeds (Ordóñez Pereda et al., 2005). In this study, the texture was rated 2.96, which places it as having slightly to highly rough texture. The fact that the animals were slaughtered at approximately three years of age might have contributed to increase in the size of the bundles of muscle fibers and consequently to reduction in the score obtained in this evaluation.

Marbling, which reflects the intramuscular-fat deposition rate, was classified as a trait with no difference between treatments. The absence of response in marbling degree can be explained by the absence of variation in SFT, since, according to Sainz and Vernazza Paganini (2004), there is a high correlation between the amount of fat in the carcass and marbling. Deposition of intramuscular fat is a variable that directly influences the meat juiciness (Cross et al., 1986), thus changing its organoleptic properties, its quality, and consequently the preference of the consumer for the product (Webb et al., 2005). According to Berg and Butterfield (1976), fat deposition is related to factors like breed, sexual status, energy level of the diet and slaughter weight, and heavier animals at adult age start depositing intramuscular fat later than lighter adult animals. Thus, the low deposition of intramuscular fat observed in this study can be explained by the fact that the animals were uncastrated and because of the slaughter weight, which did not allow them to reach a higher degree of intramuscularfat deposition.

The results obtained regarding the chemical composition of the meat diverge from those found by Miotto et al. (2012), who did not observe changes in the moisture and protein content in the meat, but did find increase in the mineral contents of the meat as corn was replaced by BMB, which was also observed in the present study. Although no difference was observed in the EE content of the meat, it was low irrespective of the diet, which is due to the low degree of intramuscular-fat deposition in the carcass. According to Abrahão et al. (2005), greater amounts of ether extract in the meat are a consequence of carcasses with a greater fat cover degree. Since there was no significant difference in marbling or fat-cover degree of the carcasses, the EE content in the meat also showed no variation.

The use of ground corn, due to the greater energy uptake promoted by the diets, provided increase in the weight of important cuts present in the $\mathrm{PC}$, such as striploin and cap of rump; this result is associated with increase in carcass weight, demonstrated by the significant correlations between these variables and by differences in the growth speed of the muscles that compose the secondary cuts, as is the case of striploin, which shows late development 
compared with the other cuts of the PC (Owens et al., 1993). Bonilha et al. (2007) found increase in the weight of the striploin of Caracu cattle compared with Nellore animals, and attributed this increase to the higher carcass weight and better conformation of the former. It is worth stressing that striploin, cap of rump and topside are cuts of high commercial value and that decrease in their participation in the carcass with the use of whole corn grain results in reduction in the revenue obtained with its sale. The variation observed in the proportion of cube roll cap, however, is linked to the fact that its weight is highly variable, since this cut is subjected to the carcass cleaning process, with removal of injuries resulting from fights between animals moments before slaughter, which consequently reduces the participation of this cut in the pistol cut.

For the majority of cuts of the PC, there was similarity in absolute weight and participation of $\mathrm{PC}$, which demonstrates the feasibility of including BMB and of using ground corn in the diets of young bulls, given that its use allows for satisfactory production of the commercial cuts. The number of cuts in which variations could be observed was low, which, according to Berg and Butterfield (1976), is because the muscles of the pistol cut region develop early, and as the animal ages, its growth speed is decreased, which in turn reduces the occurrence of variation in the collected data.

\section{Conclusions}

The commercial proportions of commercial cuts, carcass characteristics and qualitative meat characteristics are not changed with inclusion of up to $412.4 \mathrm{~g} / \mathrm{kg}$ babassu mesocarp bran in the diet of crossbred young bulls. Use of whole corn grains reduces the hot slaughter weight and can modify the proportion of tissues and cuts like striploin and cap of rump, which present a high commercial value, and this may reduce the revenues obtained with commercialization of these products by the meat-packing plants.

\section{Acknowledgments}

Financial support was received from CNPq (National Council for Scientific and Technological Development) in a partnership with Tobasa Indústria e Comércio S. A.

\section{References}

Abrahão, J. J. S.; Prado, I. N.; Perotto, D. and Molleta, J. L. 2005. Características de carcaça e da carne de tourinhos submetidos a dietas com diferentes níveis de substituição do milho por resíduo úmido da extração da fécula de mandioca. Revista Brasileira de Zootecnia 34:1640-1650.

Alleoni, G. F. 1955. Avaliação da gravidade específica da carcaça,da composição q química e física, dos cortes da costela para estimar a composição corporal de novilhos Nelore na fase de acabamento. 1995. Tese (D.Sc.). Faculdade de Ciências Agrárias e Veterinárias da Universidade Estadual Paulista, Jaboticabal.

Álvarez, J. M.; Rodríguez Iglesias, R. M.; García Vinent, J.; Giorgetti, H.; Rodríguez, G. and Baselga, M. 2012. Introduction of sheep meat breeds in extensive systems: Lamb carcass characteristics. Small Ruminant Research 109:9-14.

AOAC - Association of Official Analytical Chemists. 1995. Official methods of analysis. 16th ed. AOAC International, Arlington, VA.

Berg, R. T. and Butterfield, R. M. 1976. New concepts of cattle growth. Sydney University Press, Sydney.

Bonilha, S. F. M.; Packer, I. U.; Figueiredo, L. A.; Alleoni, G. F.; Resende, F. D. and Razook, A. 2007. Efeito da seleção para peso pós-desmame sobre características de carcaça e rendimento de cortes cárneos comerciais de bovinos. Revista Brasileira de Zootecnia 36:1275-1281.

Casey, N. H.; Van Niekerk, W. A. and Webb, E. C. 2003. Goat meat. p.2937-2944. In: Encyclopedia of food sciences and nutrition. Caballero, B.; Trugo, L. and Finglass, P., eds. Academic Press, London.

Climaco, S. M.; Ribeiro, E. L. A.; Rocha, M. A.; Mizubuti, I. Y.; Silva, L. D. F.; Noro, L. Y. and Turini, T. 2006. Características de carcaça e qualidade de carne de bovinos inteiros ou castrados da raça Nelore, suplementados ou não durante o primeiro inverno. Ciência Rural 36:1867-1872.

Costa, E. C.; Restle, J.; Vaz, F. N.; Alves Filho, D. C.; Bernardes, R. A. L. C. and Kuss, F. 2002. Características da carcaça de novilhos Red Angus superprecoces abatidos com diferentes pesos. Revista Brasileira de Zootecnia 31:119-128.

Cross, H. R.; Durland, P. R. and Seidman, S. C. 1986. Sensory qualities of meat. p.279-320. In: Muscle as food. Bechtel, P. J., ed. Food Science and Technology Series. Academic Press, New York.

Cruz, R. S. 2012. Inclusão de farelo do mesocarpo do babaçu em dietas com diferentes níveis de concentrado para bovinos alimentados em confinamento. Tese (D.Sc.). Escola de Medicina Veterinária e Zootecnia/Universidade Federal do Tocantins, Araguaína.

Fernandes, H. J.; Tedeschi, L. O.; Paulino, M. F. and Paiva, L. M. 2009. Determination of carcass and body fat composition of grazing crossbred bulls using body measurements. Journal of Animal Science 88:1442-1453.

Ferreira, J. J.; Brondani, I. L.; Leite, D. T.; Restle, J.; Alves Filho, D. C.; Missio, R. L.; Heck, I. and Segabinazzi, L. R. 2006. Características da carcaça de tourinhos Charolês e mestiços Charolês x Nelore terminados em confinamento. Ciência Rural 36:191-196.

Hankins, O. G. and Howe, P. E. 1946. Estimation of the composition of beef carcasses and cuts. Technical bulletin - USDA, 926. Washington, D.C.

Henrique, W.; Sampaio, A. A. M.; Leme, P. R.; Lanna, D. P. D. and Alleoni, G. F. 2006. Ganhos de peso, taxa de deposição e composição química corporal de tourinhos Santa Gertrudes confinados, recebendo alto concentrado e níveis crescentes de polpa cítrica peletizada. Revista Brasileira de Zootecnia 35:1178-1185.

Igarasi, M. S.; Arrigoni, M. B.; Hadlich, J. C.; Silveira, A. C.; Martins, C. L. and Oliveira, H. N. 2008. Características de carcaça e parâmetros de qualidade de carne de bovinos jovens alimentados com grãos úmidos de milho ou sorgo. Revista Brasileira de Zootecnia 37:520-528.

Klophenstein, T. J.; Erickson, G. E. and Bremer, V. R. 2008. BoardInvited Review: Use of distillers by products in the beef cattle feeding industry. Journal of Animal Science 86:1223-1231. 
Loken, B. A.; Maddock, R. J.; Stamm, M. M.; Rush, I.; Quinn, S. and Lardy, G. P. 2009. Growing rate of gain on subsequent feedlot performance, meat, and carcass quality of beef steers. Journal of Animal Science 87:3791-3997.

McPhee, M. J.; Oltjen, J. W.; Famula, T. R. and Sainz, R. D. 2006. Meta-analysis of factors affecting carcass characteristics of feedlot steers. Journal of Animal Science 84:3143-3154.

Miotto, F. R. C.; Restle, J.; Neiva, J. N. M.; Lage, M. E.; Castro, K. J. and Alexandrino, E. 2012. Farelo do mesocarpo do babaçu na terminação de tourinhos: características da carcaça e cortes secundários do traseiro especial. Ciência Animal Brasileira 13:440-449.

Müller, L. 1987. Normas para avaliação de carcaça e concurso de carcaças de novilhos. 2.ed. Universidade Federal de Santa Maria, Santa Maria.

NRC - National Research Council. 2001. Nutrient requirements of beef cattle. 7th ed. National Academy Press, Washington, DC.

Ordóñez Pereda, J. A.; Rodriguez, M. I. C.; Álvez, L. F.; Sanz, M. L. G.; Minguillón, G. D. G. F.; Perales, L. de La H. and Cortecero, M. D. S. 2005. Tecnología de los alimentos - alimentos de origen animal. v.2. Editorial Síntesis, S.A., Madrid, Espanha.

Owens, F. N.; Dubeski, P. and Hanson, C. F. 1993. Factors that alter the growth and development of ruminants. Journal of Animal Science 71:3138-3150.

Pacheco, P. S.; Silva, J. H. S.; Restle, J.; Arboitte, M. Z.; Brondani, I. L.; Alves Filho, D. C. and Freitas, A. K. 2005. Características quantitativas da carcaça de novilhos jovens e superjovens de diferentes grupos genéticos. Revista Brasileira de Zootecnia 34:1666-1677.

Sainz, R. D. and Vernazza Paganini, R. F. 2004. Effects of different grazing and feeding periods on performance and carcass traits of beef steers. Journal of Animal Science 82:292-297.

Schoonmaker, J. P.; Loerch, S. C.; Turner, T. B.; Moeller, S. J.; Rossi, J. E.; Dayton, W. R.; Hathaway, M. R. and Wulf, D. M. 2002. Effect of an accelerated finishing program on performance, carcass characteristics, and circulating insulin-like growth factor I concentration of early-weaned bulls and steers. Journal of Animal Science 80:900-910.

Silva, N. R.; Ferreira, A. C. H.; Faturi, C.; Silva, G. F.; Missio, R. L.; Neiva, J. N. M.; Araújo, V. L. and Alexandrino, E. 2012. Desempenho em confinamento de bovinos de corte, castrados ou não, alimentados com teores crescentes de farelo do mesocarpo de babaçu. Ciência Rural 42:1882-1887.

Vaz, F. N. and Restle, J. 2000. Aspectos qualitativos da carcaça e da carne de machos Hereford, inteiros ou castrados, abatidos aos quatorze meses. Revista Brasileira de Zootecnia 29:1894-1901.

Vaz, F. N.; Restle, J.; Vaz, R. Z.; Brondani, I. L.; Bernardes, R. A. C. and Faturi, C. 2002. Efeitos de raça e heterose na composição física da carcaça e na qualidade da carne de e Nelore. Revista Brasileira de Zootecnia 31:376-386.

Webb, E. C.; Casey, N. H. and Simela, L. 2005. Goat meat quality. Small Ruminant Research 60:153-166. 